\title{
On the Construction of Higher Vocational Teachers' Ethnics in Education Poverty Alleviation
}

\author{
Pei Zhang \\ School of Chemical Engineering, Yunnan Open University, Kunming 650500, Yunnan, China \\ Email: 363164339@qq.com
}

\begin{abstract}
: 2020 is the year of decisive victory in building a well-off society in an all-round way, and decisive battle against poverty. Higher vocational colleges need a team of teachers with good ethics and style, as well as both ability and political integrity. Higher vocational teachers should use their own wisdom and choose scientific teaching methods. They should also warm students with love and influence students with noble teacher ethics, so that every impoverished student can learn something. In the end, this can achieve education poverty alleviation, and higher vocational teachers can contribute their own strength to the country's poverty alleviation.

Keywords: higher vocational teachers, education poverty alleviation, teachers' ethics
\end{abstract}

\section{Introduction}

2020 is an extraordinary year. While facing the severe epidemic of new crown pneumonia, it is also a year of decisive victory in building a moderately prosperous society in all respects and a decisive battle against poverty. President Xi once said, "To build a moderately prosperous society in an all-round way, one cannot be less, and one cannot be left behind on the road to common prosperity." Precision poverty alleviation requires the joint efforts of the whole society. Higher vocational colleges have the responsibility and ability to contribute to the nation's poverty alleviation. In order to do a good job in poverty alleviation in higher vocational education, higher vocational teachers need to work together so that every poor student can learn something, so as to finally achieve education poverty alleviation.

Most of the students in our school come from rural Yunnan. Many students come from remote mountainous areas, even from impoverished villages and households. It is not easy for them to come to the provincial capital of Kunming to study. Many students rely on their parents to sell pigs and work part-time for them to study. The children in the mountains walked out of the mountains and entered the big cities to go to college. In addition to seeking academic status, they also wanted to find an ideal job after graduation and take responsibility for poor families. This is their Chinese dream.

But often reality is always a little disturbing. After entering the university, the young and lovely young students were originally a blank sheet of paper and could draw the latest and most beautiful pictures. In less than two semesters, some people changed. In daily life, we talk about food and clothing, and compare with each other. There are a lot of students who are not enterprising and live by themselves. They faced difficulties in finding a job two and a half years later. Either their own ability level is too big compared with the graduates of other higher vocational colleges, and the employer chooses the best, leading them to lose the election; or they have poor eyesight and are unwilling to do heavy work in science and engineering. At this time, if the school came forward and racked their brains to help them solve the employment problem, it would be too late to make up for it. Originally, children from rural areas came to study to learn a skill and find a good job after graduation to get rid of poverty. Why wait for them to look for jobs in the society after graduation, so there will be an embarrassing situation of being picked by employers and having difficulties in finding jobs?

To solve this problem, it is necessary to interpret the purpose of running higher vocational schools. That is to serve the purpose, emphasize employment-oriented, and take the development path of combining production, teaching and research. It is also the glorious duty and goal of our higher vocational teachers to allow graduates to have the ability to work directly and be more competitive in the job market. Therefore, it is very important to cultivate a team of teachers who listen to the party's command, have a good style, and have good skills. Ten years of trees, a hundred years of trees. At that time, Yan'an (AntiJapanese Military and Political University) trained a large number of cadres who were able to conquer and fight, and made great contributions to the liberation of China and the construction of a new China. Why is this? Just because the Military and Political University has a good faculty.

General Secretary Xi said: "my country's economy depends on the real economy for support, which requires a large number of professional and technical personnel, and a large number of craftsmen from big countries. Therefore, vocational 
education is promising. Three hundred and sixty lines can be the best." As the only one in Yunnan Province. One by one has decades of experience in running schools, multi-disciplinary, multi-professional vocational and technical colleges, Yunnan National Defense Industry Vocational and Technical College has a team of teachers with excellent teaching style and both morality and ability, which can create a unique and good education The environment has become a first-class base for continuously sending qualified talents to the whole province and the whole country.

Today, the battle for targeted poverty alleviation has been fully victorious. The revitalization of the countryside is being promoted in an all-round way. Teachers in higher vocational colleges need to have a stronger sense of urgency. Education to get rid of poverty is our glorious mission, and it is also our obligatory social responsibility. Principal Zhang Guimei, a 63-year-old model of the era, has persisted in the education undertakings in the impoverished mountainous areas of western Yunnan for decades. She founded the country's first all-free girls' high school 12 years ago and has helped more than 1,800 poor girls realize their college dreams so far. Principal Zhang used her life to create an "educational miracle" in the mountains under the difficult conditions of running a school. Principal Zhang Guimei faces students from Dashan, with poor families, poor cultural foundations, and poor living habits. But she firmly believes that helping a child to receive a higher level of education is to help a family out of poverty.

\section{How higher vocational teachers can contribute to the nation's poverty alleviation in their jobs?}

The author mainly talks about how higher vocational teachers can devote themselves to the strategic actions of targeted poverty alleviation from the following three aspects.

First of all, the podium is the sacred high ground for teachers. Teachers need to work hard, work hard, and make selfless dedication. Since 2018, our school has attached great importance to the construction of "Ideological and Political Courses and Curriculum Ideological and Political", allowing teachers to plant the seeds of "moral education" in the classroom from their own professional courses on the podium, and align the fundamental tasks of Lide Shuren Cultivate the organic integration of compound technical and technical talents. "Morality" is the product of the development of higher vocational colleges and the soul of teachers' growth. Teachers should be responsible for the all-round development of students, and cultivate students to have a sound personality, noble character, tolerance, and academic success, and take it as the lifelong pursuit of teaching. Teachers should integrate morality, knowledge, and ability into the whole process of talent training, not only to make a living for students, but also to find ways for students, so as to accumulate positive energy for the sustainable development of students.

Secondly, higher vocational colleges should improve the quality of teachers through the construction of teacher ethics and style. Teachers must learn to teach in learning and improve in research. In order to give students a "bowl of water", teachers need to work hard to accumulate a "bucket of water", and they must skillfully inject the research results into the classrooms of the courses they teach. In the process of helping higher vocational education help poverty alleviation, we must go from "giving fish" to "teaching people to fish", pay close attention to the industry and industry frontier knowledge and technological progress, and keep pace with the times instead of sticking to conventions. Teachers must master a skill through various channels to help a large number of children from poor families in the school find employment soon after graduation. In this way, there is hope for their families to get rid of poverty, and it can also give everyone a chance to shine in life.

Finally, the frontline teachers of higher vocational colleges should have a responsibility to treat students as their own children. Some students faced by higher vocational teachers are indeed not very obedient. If the teacher is in charge of them, they will roll their eyes at the teacher and even curse a few words. If the teacher does not care about them, their academic performance is very poor, which also affects other students. The teacher was dry-mouthed above the podium, and they turned a deaf ear under the podium. In fact, teachers are a profession of conscience. As long as the teacher is worthy of his own conscience, there is no need to pay too much attention to these external things. Moreover, the current students are 18 or 9 years old, saying that they are not big, and many reasons have not been understood yet. In many things, we still need our teachers to guide. The author's idea is that the teacher takes the trouble to say that even if only one person understands it and changes it for this reason, it is worth it. After all, good medicine is good for the disease, instead of seeing that your child is sick, letting it worsen, and not treating it. Even a classmate did not listen to the teacher's words, but after a few years, when the classmates recalled the teacher, at least they would not use the words "irresponsible" to evaluate the teacher.

\section{Conclusion}

Education is a secret and great guardian, and the morality of teachers is one of the most important levels for teachers to complete this guardianship. To establish morality first establish oneself, and to establish people first establish oneself. Higher 
vocational teachers should use their own wisdom and choose scientific teaching methods. Teachers should warm students with love and show their noble morality to influence students. National leaders once said: "One vocational education, one job, one family out of poverty. Higher vocational education has made a huge contribution to solving the employment of poor students." The frontline teachers of higher vocational colleges have the responsibility to help students realize their Chinese dream together with love, and contribute to the nation's poverty alleviation.

\section{References}

[1] General Secretary Xi Jinping proposed "precise poverty alleviation" [EB/OL]. (2019-11-28) Available from: https:// baijiahao.baidu.com/s?id=1651437403872292144\&wfr=spider\&for=pc

[2] Li Zhongguo, Li Xingcheng. Research on optimization of vocational education and poverty alleviation mechanism. Journal of National Academy of Educational Administration. 2017; (12): 88-94.

[3] Notice of the Ministry of Education and other six departments on the issuance of the "Modern Vocational Education System Construction Plan (2014-2020)" [EB/OL]. (2014-06 -16) Available from: http://www.moe. gov.cn/srcsite/A03/ moe_1892/moe_630/201406/t20140623_170737.html

[4] Tan Xuewen. Research on perfecting the current targeted poverty alleviation system and mechanism. Journal of China Agricultural University (Social Science Edition). 2017; (5): 42-50.

[5] Wang Kai. Three major trends in the development of the concept of teacher ethics in my country in recent years. Chinese Journal of Education. 2013; (01): 49-52.

[6] Chen Liang. On the classics and human teachers. Journal of the Party School of Guilin Municipal Committee. 2008; 8(02): 59-62. 